\title{
Konsep Ekologis pada Arsitektur di Desa Bendosari
}

\author{
Ema Yunita Titisari, Joko Triwinarto S., dan Noviani Suryasari \\ ${ }^{1}$ Jurusan Arsitektur/Fakultas Teknik Universitas Brawijaya \\ ema.yunita@gmail.com
}

\begin{abstract}
ABSTRAK
Desa Bendosari tengah berupaya mengembangkan potensi alamiahnya untuk kegiatan agraris dan wisata. Dikhawatirkan implikasi dari kegiatan wisata adalah pada kerusakan lingkungan. Untuk itu perlu dibuat serangkaian kebijakan terkait tata ruang kawasan agar nilai-nilai kearifan lokal. Penelitian ini berupaya untuk mengidentifikasi konsep ekologis masyarakat Desa Bendosari dengan mengangkat arsitektur sebagai obyek penelitian. Unsur-unsur arsitektural yang diamati antara lain adalah ruang, struktur dan konstruksi, bahan (material bangunan), dan unsur-unsur non fisik (sosial, budaya, ekonomi, agama/kepercayaan, adat-istiadat, dan sebagainya) sebagai faktor penentu perubahan. Metode yang digunakan adalah metode deskriptif. Analisis didasarkan pada teori arsitektur ekologis. Hasil penelitian menunjukkan bahwa arsitektut Desa Bendosari masih cukup ekologis meskipun dalam beberapa hal telah mulai meninggalkan konsep ekologis terutama terkait penggnaan bahan bangunan dan teknologi baru yang tidak diadaptasikan dengan kondisi lokal.
\end{abstract}

Kata kunci: arsitektur, ekologis, desa

\section{Pendahuluan}

Kerusakan lingkungan menjadi masalah yang kian memprihatinkan. Arsitektur menjadi salah satu bidang ilmu yang dijustifikasi ikut memberi andil bagi kerusakan lingkungan. Konsep sustainable architecture menjadi salah satu upaya untuk memperbaiki kerusakan lingkungan.

Sustainable architecture ditandai dengan upaya menggali kembali nilai-nilai kearifan lokal. Arsitektur Nusantara di masa lalu menunjukkan kesetimbangan-keselarasannya dengan lingkungan alam. Arsitektur yang demikian dapat hidup bersama-sama, bahkan bersinergi dengan lingkungannya.

Desa Bendosari, Pujon, Kabupaten Malang memiliki potensi alam dan budaya cukup tinggi yang menjadi urat nadi kegiatan perekonomian masyarakat. Konsep-konsep tradisional yang masih dipegang teguh menunjukkan upaya pengelolaan lingkungan secara selaras-setimbang dengan kegiatan perekonomian masyarakat. Ancaman dari komersialisasi adat-tradisi dan potensi alamiah demi meningkatkan taraf hidup masyarakat dalam bentuk desa wisata yang sedang digiatkan saat ini menuntut untuk secepatnya disusun kebijakan berbasis kearifan lokal, dalam hal ini aspek ekologisnya demi keselamatan lingkungan binaan.

Penelitian ini sangat penting dilakukan karena dominasi faktor ekonomi dari program desa ekowisata yang digagas pemerintah Desa Bendosari perlu mendapat pengendalian agar tidak menyebabkan kerusakan lingkungan. Modernisme, tampaknya sedikit demi sedikit juga telah mengikis konsep-konsep ekologis tradisional yang arif dalam mengelola lingkungan binaan. Sebelum konsep ini benar-benar punah akibat terdesak oleh 
modernisme dan kegiatan desa wisata, maka perlu dilakukan identifikasi konsep-konsep ekologis yang ada. Tujuan jangka panjangnya adalah untuk merumuskan kebijakan perencanaan dan perancangan lingkungan binaan (arsitektur) yang ekologis dan sustainable.

Untuk itu permasalahan yang hendak dijawab dalam penelitian ini adalah: bagaimanakah konsep ekologis pada arsitektur di Desa Bendosari? Permasalahan ini akan dijawab melalui upaya mengidentifikasi konsep-konsep ekologis yang dapat ditemukan pada arsitektur di Desa Bendosari.

\section{Bahan dan Metode}

\subsection{Konsep Ekologis dalam Arsitektur}

Konsep ekologis merupakan konsep penataan lingkungan dengan memanfaatkan potensi atau sumberdaya alam dan penggunaan teknologi berdasarkan manajemen etis yang ramah lingkungan. Pola perencanaan dan perancangan Arsitektur Ekologis (Eko-Arsitektur) adalah sebagai berikut:

1. Elemen-elemen arsitektur mampu seoptimal mungkin memberikan perlindungan terhadap sinar panas, angin dan hujan.

2. Intensitas energi yang terkandung dalam material yang digunakan saat pembangunan harus seminimal mungkin, dengan cara-cara:

a. Perhatian pada iklim setempat

b. Substitusi, minimalisasi dan optimasi sumber energi yang tidak dapat diperbaharui

c. Penggunaan bahan bangunan yang dapat dibudidayakan dan menghemat energi

d. Pembentukan siklus yang utuh antara penyediaan dan pembuangan bahan bangunan, energi, atau limbah dihindari sejauh mungkin

e. Penggunaan teknologi tepat guna yang manusiawi

Menurut Yeang (2006), pendekatan ekologi dalam arsitektur didefinisikan dengan Ecological design is bioclimatic design, design with the climate of the locality, and low energy design. Dengan demikian terdapat integrasi antara kondisi ekologi lokal, iklim mikro dan makro, kondisi tapak, program bangunan atau kawasan, konsep, dan sistem yang tanggap terhadap iklim, serta penggunaan energi yang rendah. Integrasi dapat dilakukan pada tiga tingkatan:

1. Integrasi fisik dan karakter fisik ekologi setempat (tanah, topografi, air tanah, vegetasi, iklim, dsb.)

2. Integrasi sistem-sistem dengan proses alam (cara penggunaan air, pengolahan dan pembuangan limbah cair, sistem pembuangan dari bangunan, pelepasan panas dari bangunan, dsb.)

3. Integrasi penggunaan sumber daya yang mencakup penggunaan sumber daya alam yang berkelanjutan

Pendekatan ekologi dalam arsitektur yang lain yaitu menurut Frick (1998) adalah bahwa eko-arsitektur mencakup keselarasan antara manusia dan alam. Eko-arsitektur mengandung juga dimensi waktu, alam, sosio kultural, ruang dan teknik bangunan. Ekoarsitektur bersifat kompleks, mengandung bagian-bagian arsitektur biologis (kemanusiaan dan kesehatan), serta biologi pembangunan. Oleh sebab itu eko-arsitektur bersifat holistik dan mengandung semua bidang.

Pada cakupan yang lebih luas, Cowan dan Ryn (1996) mengemukakan prinsip-prinsip desain yang ekologis sebagai berikut: 
1. Solution Grows from Place: solusi atas seluruh permasalahan desain harus berasal dari lingkungan di mana arsitektur itu akan dibangun. Prinsipnya adalah memanfaatkan potensi dan sumber daya lingkungan untuk mengatasi setiap persoalan desain. Pemahaman atas masyarakat lokal, terutama aspek sosial-budayanya juga memberikan andil dalam pengambilan keputusan desain. Prinsip ini menekankan pentingnya pemahaman terhadap alam dan masyarakat lokal. Dengan memahami hal tersebut maka kita dapat mendesain lingkungan binaan tanpa menimbulkan kerusakan alam maupun 'kerusakan' manusia.

2. Ecological Acounting Informs Design: perhitungan-perhitungan ekologis merupakan upaya untuk memperkecil dampak negatif terhadap lingkungan. Keputusan desain yang diambil harus sekecil mungkin memberikan dampak negatuf terhadap lingkungan.

3. Design with Nature: arsitektur merupakan bagian dari alam. Untuk itu setiap desain arsitektur harus mampu menjaga kelangsungan hidup setiap unsur ekosistem yang ada di dalamnya sehingga tidak merusak lingkungan. Prinsip ini menekankan pada pemhaman mengenai living process di lingkungan yang hendak diubah atau dibangun.

4. Everyone is a Designer: melibatkan setiap pihak yang terlibat dalam proses desain. Tidak ada yang bertindak sebagai user atau participant saja atau designer/ arsitek saja. Setiap orang adalah participant-designer. Setiap pengetahuan yang dimiliki oleh siapapun dan sekecil apapun harus dihargai. Jika semua orang bekerjasama untuk memperbaiki lingkungannya, maka sebenarnya mereka memperbaiki diri mereka sendiri.

5. Make Nature Visible: proses-proses alamiah merupakan proses yang siklis. Arsitektur sebaiknya juga mampu untuk melakukan proses tersebut sehingga limbah yang dihasilkan dapat ditekan seminimal mungkin.

Hui (2001) melengkapi prinsip tersebut di atas dengan mengemukakan prinsip understanding people yang intinya pada upaya memahami konteks budaya, agama, ras, perilaku, dan kebiasaan (adat) masyarakat yang akan diwadahi oleh arsitektur. Prinsipprinsip Hui yang lain adalah: Understanding Place, Connecting with Nature, Understanding Natural Processes, Understanding Environmental Impact, dan Embracing Co-creative Design Processes.

Teori-teori desain ekologis di atas perlu dicermati dengan memahami kenyataan bahwa arsitektur nusantara merupakan arsitektur yang hidup dalam kebersamaan dengan lingkungan alam dan lingkungan sosialnya, serta dilandasi oleh prinsip keTuhanan; bukan arsitektur yang bersifat individual. Untuk itu, pada pelaksanaanya sangat mutlak dijunjung tinggi azas utama yaitu kasih-sayang dan kepemurahan. Bentuknya adalah rasa saling menghargai (tepa-selira), kerjasama (gotong-royong) dan saling member. Azas utama inilah yang semestinya dijaga agar tetap lestari karena kegiatan industri yang didominasi faktor ekonomi sangat mengabaikan azas tersebut.

\subsection{Unsur-unsur Arsitektural}

Unsur/elemen pembentuk bangunan dijabarkan oleh Ching (2000) sebagai bagianbagian yang memiliki keterkaitan satu sama lain, dan keterkaitan dengan sistemnya membentuk satu kesatuan tatanan yang sifatnya konseptual. Dari 5 unsur yang ada terdapat dua unsur penting yaitu bentuk dan ruang. Kelima unsur tersebut terdiri atas:

1. bentuk: titik temu antara massa dan ruang, terbentuk oleh berbagai unsur yang dapat dikenali secara visual, mempunyai ciri-ciri visual yang dibangun oleh dimensi, warna, tekstur, dan wujud. 
2. ruang: volume yang terlingkupi, terbentuk, terorganisir maupun terisi oleh unsur-unsur massa.

3. fungsi: sistem akomodasi bagi tuntutan program yang mengacu pada kebutuhan/persyaratan pengguna bangunan.

4. teknik: sistem struktur, kekuatan pelingkup, sebagai tanggapan terhadap tuntutan kenyamanan, proteksi lingkungan, kesehatan dan daya tahan.

5. konteks: situs (tempat) dan lingkungan, faktor alam mencakup iklim (angin, matahari, temperatur, hujan), dan faktor budaya.

Jika merujuk pada teori dasar arsitektur, maka unsur utama arsitektur selalu dikaitkan dengan aspek fungsi, estetika, dan struktur. Ditinjau dari prinsip-prinsip desain ekologis, maka beberapa indikator penting bagi konsep ekologis meliputi unsur-unsur:

1. Aspek struktur dan konstruksi

2. Aspek bahan bangunan

3. Aspek sumber-sumber energi dan pemanfaatannya bagi kehidupan sehari-hari.

4. Aspek manajemen limbah (utilitas).

5. Aspek ruang, meliputi zonasi, tata ruang, dan fungsinya.

\subsection{Metode Penelitian}

Penelitian ini menggunakan metode kualitatif dengan pendekatan deskriptif (Darjosanjoto, 2006; Moleong, 2002). Lokasi penelitian adalah di Desa Bendosari, Kecamatan Pujon, Kabupaten Malang dan akan dilangsungkan selama bulan April-Juli 2012. Obyek yang diteliti adalah arsitektur yang berada di kawasan pedesaan. Letak Desa Bendosari adalah di wilayah barat Kabupaten Malang, pada jalur Malang-Jombang. Luas wilayahnya 269,23 ha, dan terdiri dari 5 (lima) dusun, yaitu Dusun Cukal, Dusun Dadapan Wetan, Dusun Dadapan Kulon, Dusun Ngeprih dan Dusun Tretes.
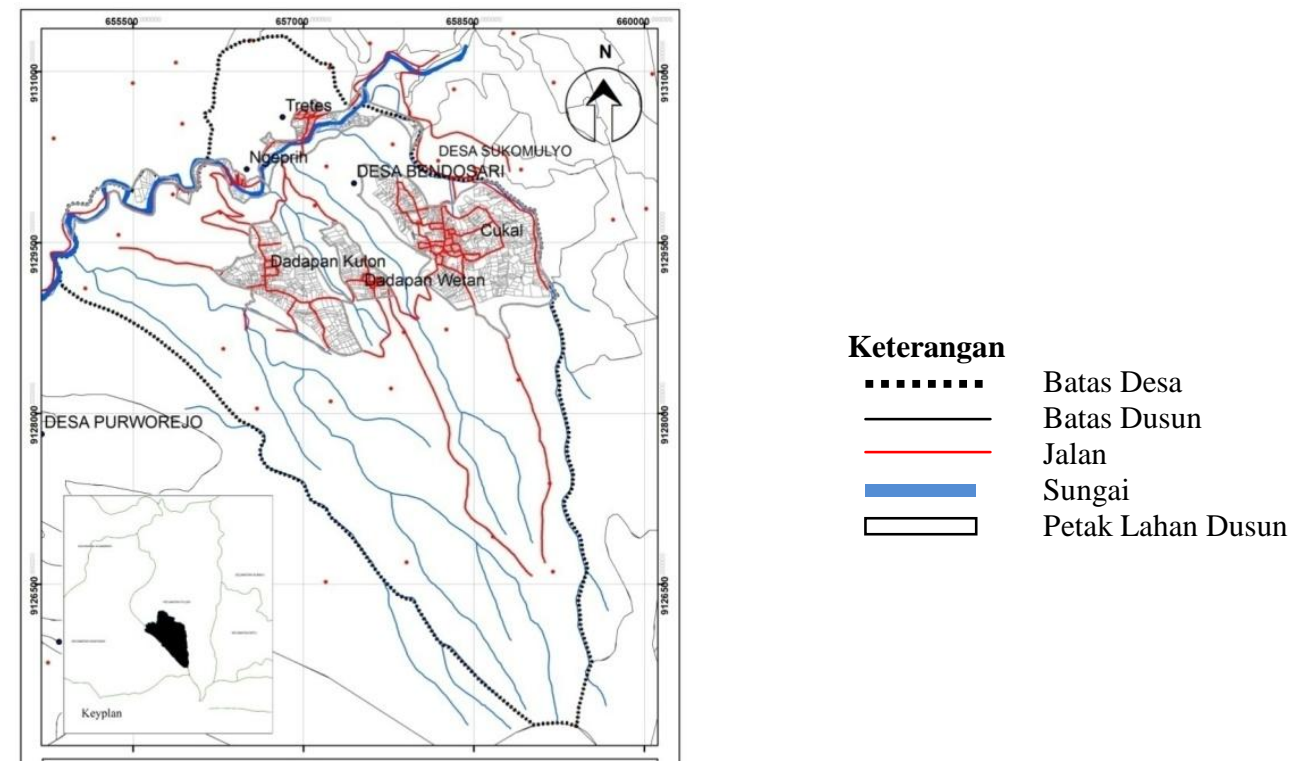

Gambar 1. Peta Desa Bendosari (Sumber: Kantor Desa Bendosari)

Langkah-langkah penelitian adalah sebagai berikut:

1. Grand Tour, untuk melihat secara keseluruhan obyek penelitian serta menentukan sampel-sampel yang akan dipilih untuk diteliti secara lebih mendalam. 
2. Setelah sampel ditentukan, selanjutnya dilakukan observasi dan pencatatan mengenai aspek-aspek ekologis pada obyek penelitian.

3. Identifikasi unsur-unsur arsitektural sesuai dengan konsep desain ekologis. Pada tahap ini akan diidentifikasi aspek-aspek arsitektural di lingkup mikro arsitektur yang kemungkinan di dalamnya terkandung implikasi penerapan konsep desain ekologis. Parameter eko-arsitektur untuk melihat dan mengidentifikasi hal tersebut adalah konsep ekologis dalam arsitektur menurut Hui (2001), yang sejalan pula dengan Cowan dan Ryn (1996) yaitu:

a. Understanding People

b. Understanding Place

c. Connecting with Nature

d. Understanding Natural Processes

e. Understanding Environmental Impact

$f$. Embracing co-creative design Processes

Variabel penelitian ini meliputi:

1. Variabel arsitektur, meliputi: bahan bangunan, struktur dan konstruksi, utilitas, fungsi ruang, pemakai/pengguna ruang, dan tata ruang. Pengamatan ini dilakukan pada waktu yang berbeda-beda dengan responden para ahli bangunan, perangkat desa, tetua adat, dan pengguna ruang

2. Variabel non-fisik yang diobservasi dan dianalisis meliputi peraturan-peraturan tertulis dan tak tertulis, norma-norma adat terkait konsep ekologis, tradisi, dan sebagainya.

\section{Hasil dan Pembahasan}

Konsep ekologis pada arsitektur di Desa Bendosari yang dapat diidentifikasi adalah sebagai berikut:

1. Understanding People

a. Aspek kepercayaan berperan dalam menentukan waktu pendirian rumah, dan hal-hal tertentu terkait desain rumah. 'Dukun' atau 'kyai' adalah orang-orang yang berperan dalam menentukan hal-hal tersebut. Untuk bahan bangunan, saat ini tak lagi menggunakan bahan bangunan lokal sehingga tidak memerlukan konsultasi dengan dukun atau kyai tersebut. Tujuan konsultasi serta selamatan adalah agar selamatsejahtera proses pembangunan hingga saat rumah tersebut dihuni.

Pada ruang rumah tinggal terdapat ruang atau tempat untuk meletakkan sesaji pada waktu-waktu tertentu. Beberapa orang memaknai khusus area pintu masuknya. Biasanya ada yang meletakkan sesaji atau simbol-simbol lain di bagian atas pintu yang bertujuan sebagai penolak bala (bencana).

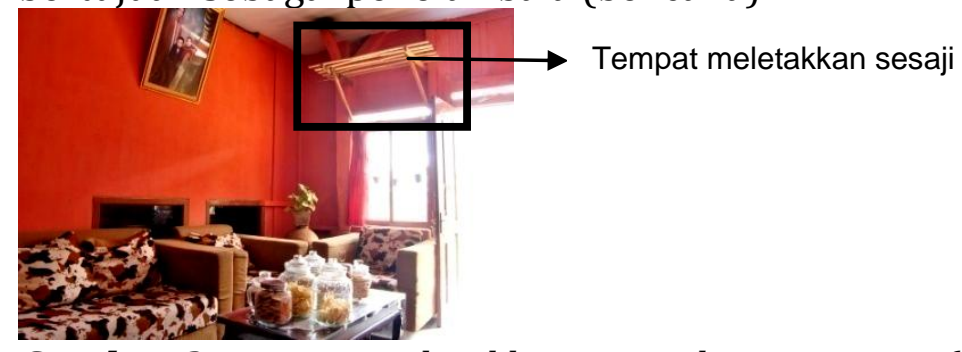

Gambar 2. Tempat meletakkan sesaji di ruang tamu (Dok. Nur dan Biendra, 2012) 
b. Mata air adalah wilayah yang disakralkan. Sesaji pada upacara sedekah bumi diletakkan di mata air. Masyarakat masih sangat menjaga dan memegang teguh kepercayaan ini.

c. Partisipasi sosial merupakan social capital yang masih sangat kental dalam masyarakat. Pada proses pendirian rumah, partisipasi ini dilakukan dalam bentuk pemberian bantuan material, pemikiran, maupun tenaga. Saat ini bantuan mendirikan rumah tidak lagi dilakukan dari awal hingga akhir proses tetapi pada proses-proses tertentu saja, seperti pada saat penggalian pondasi dan pemasangan kuda-kuda. Pada pembangunan fasilitas umum, masyarakat juga melakukannya dengan kerja bakti.

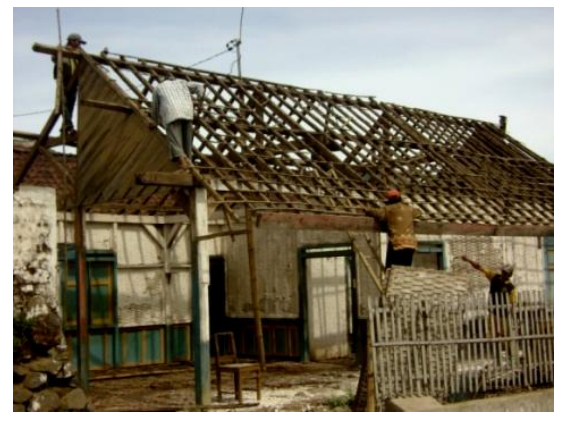

Gambar 3. Pembangunan rumah dibantu oleh para tetang.qa

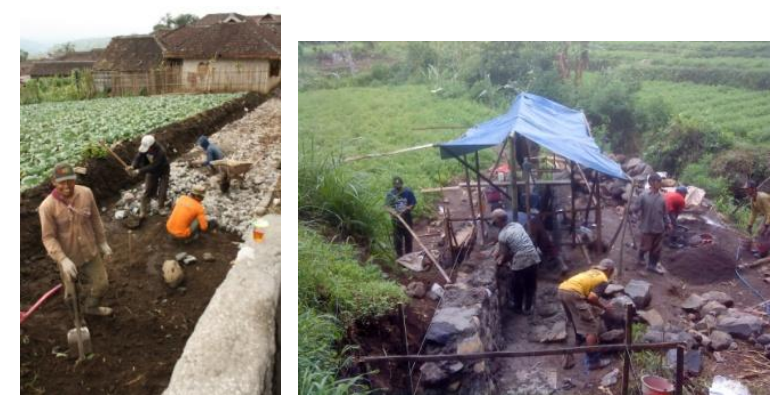

Gambar 4. Kerja bakti pembangunan fasilitas umum (jalan desa dan mikrohidro)

d. Selera masyarakat mengenai rumah tinggal mengalami perubahan pada aspek bahan bangunan, bentuk rumah, serta sistem struktur dan konstruksinya. Aspek ekonomi mendukung terjadinya perubahan tersebut.

e. Tata

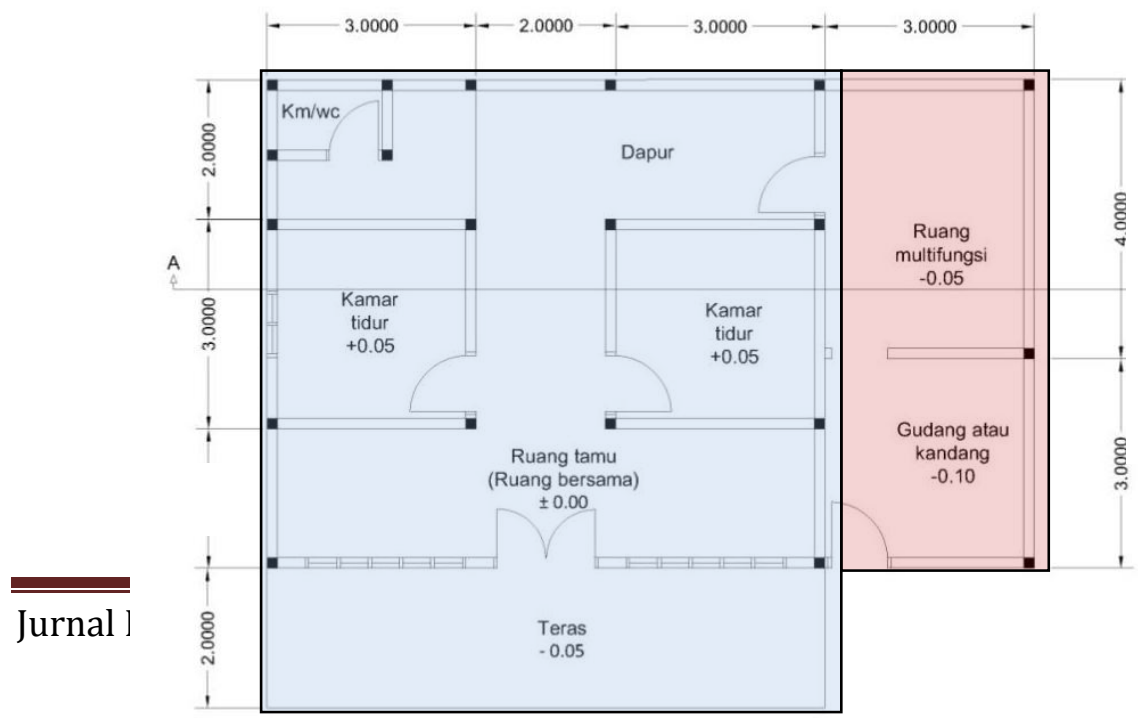

ruang rumah sesuai dengan jenis aktivitas, norma-norma sosial, selera, serta kebutuhan lainnya. Pola ruang rumah cenderung masih mengikuti pola ruang tradisional karena secara umum, norma sosial masyarakat belum mengalami perubahan, demikian pula pola budayanya. 
Gambar 5. Denah rumah, pada umumnya gudang/kandang dan dapur yang menggunakan bahan bakar kayu terletak di luar bangunan utama.
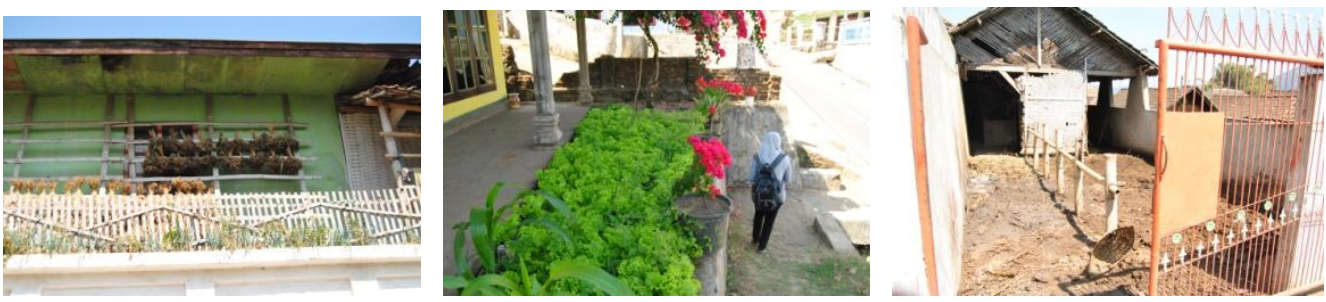

Gambar 6. Halaman samping dan depan rumah dimanfaatkan untuk area jemur, tempat bercocok tanam, dan kandang (Dok. Nur dan Biendra, 2012)
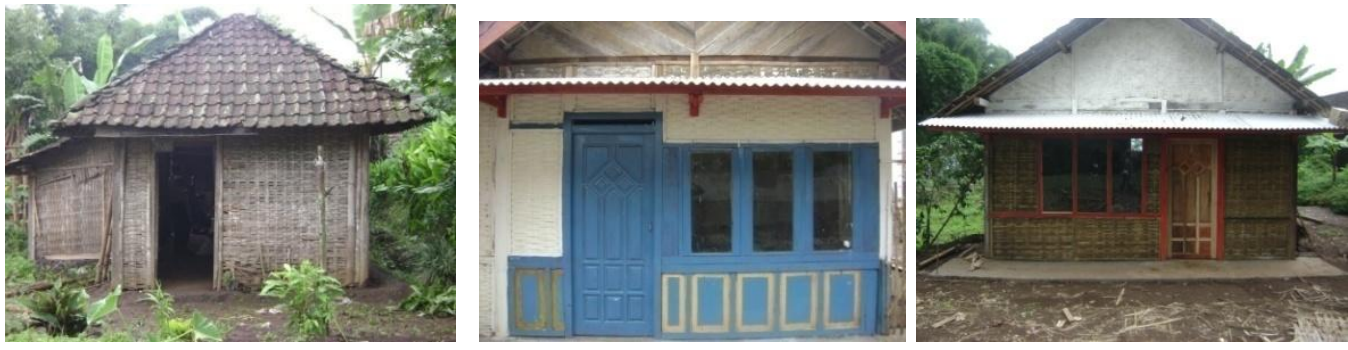

Gambar 7. Beberapa tipe rumah lama (tradisional). (Dok. Nur dan Biendra, 2012)
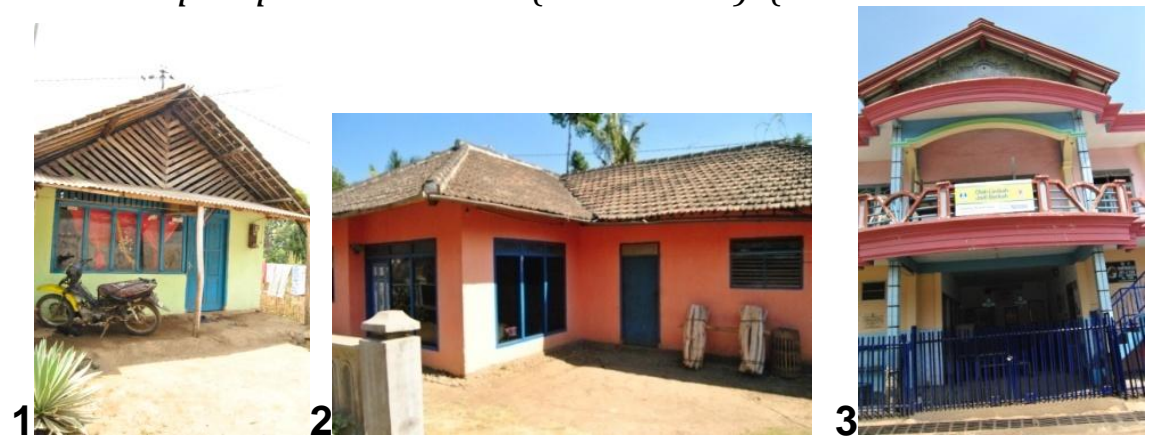

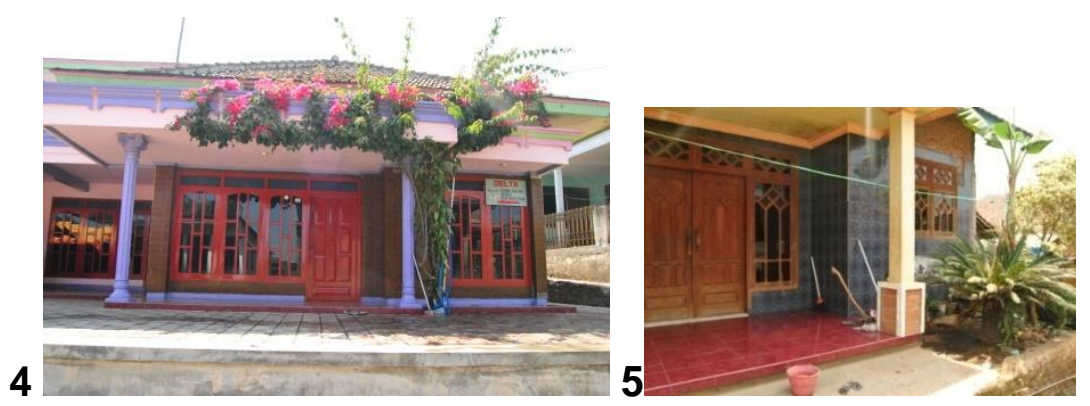

Gambar 8. Rumah-rumah yang mengalami perubahan. (Dok. Nur dan Biendra, 2012).

f. Variasi model atau gaya rumah, pemilihan material, detil-detil ornamen, warna, dan sebagainya bersifat personal, tergantung keyakinan, selera, tingkat ekonomi, dan nilainilai yang dianut. 


\section{Understanding Place}

Pemahaman terhadap kondisi site (place) ditunjukkan oleh hal-hal sebagai berikut:

a. Pengelolaan sumber daya lokal sebagai bahan bangunan dan sumber-sumber energi bagi kegiatan sehari-hari masyarakat.

b. Tanggapan arsitektur (rumah, fasilitas umum, lahan pertanian, dan lain-lain) atas permasalahan lingkungan fisik (geografis, iklim, dan lain-lain) misalnya dalam bentuk zonasi wilayah permukiman, hutan, dan lahan garapan; desain dan perletakan rumah disesuaikan dengan kontur tanah; bahan bangunan lokal yang dirancang sesuai dengan kondisi iklim (ringan, berongga, atap miring sebagai solusi masalah curah hujan dan sinar matahari, rongga bagian bawah dinding untuk mengurangi kelembaban); dan sebagainya.

c. Bambu sebagai material lokal yang masih sangat banyak dan potensial kini semakin ditinggalkan. Secara ekologis, hal ini tidak sesuai dengan konsep ekologis yang lebih mengutamakan penggunaan bahan bangunan lokal. Penggunaan kayu memang telah dibatasi sebagai upaya konservasi lingkungan

d. Jarak antara satu rumah dengan rumah lain memungkinkan pergerakan udara dan masuknya cahaya matahari ke dalam rumah. Sebagian besar tidak memanfaatkan halamannya untuk area hijau. Pohon-pohon besar yang biasanya ditanam di halaman rumah-rumah pedesaan tidak banyak ditemukan di Bendosari. Hal ini tidak terlalu mempengaruhi pergerakan udara dan penghawaan di dalam ruangan karena temperatur desa Bendosari cukup dingin, ditambah dinding rumah berpori, sehingga tanpa pohon-pohon besar di halaman pun udara di dalam rumah sudah cukup sejuk. Selain itu, posisi permukiman dikelilingi oleh areal persawahan dan hutan, dengan proporsi lahan pertanian dan hutan jauh lebih besar dibandingkan luas permukiman.

e. Perubahan gaya rumah yang mengikuti trend dan selera baru acapkali mengabaikan permasalahan iklim. Kaca, dan keramik yang dipasang di lantai maupun di dinding seringkali justru menjadi masalah bagi kenyamanan di dalam bangunan. Keramik, memang membuat rumah terlihat lebih bersih dan rapi. Namun ketika keramik itu dipasang di dinding, maka sebenarnya ia justru membuat udara di dalam ruangan lebih dingin. Dinding bata menyebabkan poripori dinding berkurang sehingga pada siang hari udata di dalam ruangan lebih panas.

f. Penggunaan kayu bakar untuk kebutuhan sehari-hari mengancam kelestarian hutan, di samping tidak efektif. Untuk itu pemerintah lokal memanfaatkan biogas yang banyak diperoleh di Bendosari untuk mensuplai kebutuhan energi rumah tangga. Sumber energi alternatif lain yang memanfaatkan potensi alamiah lokal adalah mikrohidro. Proyek ini dapat dikembangkan untuk memenuhi kebutuhan energi listrik.

\section{Connecting with Nature}

a. Dalam beberapa hal, masyarakat telah mulai meninggalkan hubungannya yang harmonis dengan alam, terutama pada aspek penggunaan bahan bangunan dan model rumah baru yang diadaptasikan dulu dengan potensi dan permasalahan lokal.n Sistem pertanian modern juga semakin menjauhkan hubungan manusiaalam akibat penggunaan pupuk dan obat-obatan pertanian yang ujungya adalah eksploitasi lingkungan. Dampaknya belum terlalu dirasakan saat ini, tetapi kasus- 
kasus lingkungan akibat penggunaan zat-zat an-organik telah terbukti di banyak tempat.

b. Hal-hal positif yang ditemukan di Bendosasri terkait konsep ini adalah perbaikan sistem utilitas untuk menjaga kebersihan dan kelestarian sungai.

\section{Understanding Natural Processes}

a. Pola permukiman yang disusun secara mengelompok secara tidak langsung merupakan upaya menjaga kelangsungan hidup ekosistem alam di luar permukiman.

b. Perubahan mindset penggunaan bahan bangunan alam ke bahan fabrikasi secara otomatis menjaga ekosistem hutan. Tetapi masyarakat perlu mendapatkan pemahaman mengenai pemanfaatan bahan alam untuk konstruksi dan regenerasinya, serta perlu juga mendapat pengetahuan mengenai dampak positif dan negatif penggunaan bahan bangunan fabrikasi. Bahan-bahan bangunan seperti semen, batu bata, dan keramik tidak diproduksi di Desa Bendosari, tetapi apabila seluruh bangunan di Indonesia menggunakan bahan yang sama untuk konstruksinya maka kerusakan lingkungan asal bahan-bahan bangunan tersebut akan semakin cepat.

c. Pola dan fungsi ruang disesuaikan dengan aktivitas sehari-hari masyarakat. Lahan pekarangan dimanfaatkan untuk fungsi-fungsi seperti pekarangan dan kandang. Hal ini menunjukkan bahwa masyarakat berupaya untuk semaksimal mungkin mampu menyediakan sumber pangan mereka secara mandiri, selain untuk dijual. Sayangnya, masyarakat belum memahami tata kelola ruang yang baik agar masing-masing kegiatan dapat berjalan dengan baik tanpa menimbulkan kesan kumuh atau kotor. Di beberapa kasus rumah ditemukan kandang yang terletak di samping rumah terlihat kotor karena sistem pembuangan limbah kotoran ternak belum didesain dengan baik. Jika dibiarkan hal ini dapat menimbulkan dampak buruk bagi kesehatan.

d. Saat ini masyarakat menjaga sumber-sumber air terutama karena kepercayaan. Perlu pemahaman bagi masyarakat mengenai konsep kelestarian lingkungan alam di baliknya, Upaya untuk meningkatkan pengetahuan mengenai teknologi peningkatan kandungan air tanah yang baru saja dilakukan adalah dengan teknik biopori. Sistem ini masih belum banyak dipraktekkan warga.

e. Manajemen limbah yang cukup baik dilakukan terkait konsep Understanding Natural Processes adalah pemanfaatan biogas untuk energi alternatif.

\section{Understanding Environmental Impact}

a. Masyarakat perlu memahami bahwa zona yang terbentuk di lingkungan permukiman mereka memiliki dampak positif bagi lingkungan. Untuk itu perubahan fungsi lahan, termasuk perluasan wilayah permukiman dan areal pertanian yang mungkin terjadi di kemudian hari perlu mempertimbangkan dampaknya terhadap lingkungan alam.

b. Pemanfaatan bahan bangunan lokal (bambu) masih sangat potensial. Bambu juga cenderung tidak menimbulkan dampak negatif bagi lingkungan dan regenerasinya cukup cepat. Namun masyarakat lebih memiih menggunakan material non lokal karena tidak mengetahui dampak negatif penggunaan bahanbahan tersebut secara eksploitatif, terutama bagi lingkungan tempat asalnya.

c. Masyarakat belum memahami dampak negatif yang akan timbul apabila air kotor limbah rumah tangga dibuang langsung ke sungai. Saluran pembuangan air kotor 
perlu dibenahi sistem dan desainnya agar lebih sehat dan tidak menimbulkan dampak negatif bagi lingkungan.

d. Dampak negatif penggunaan bahan bakar kayu adalah pada kelestarian lingkungan. Untuk itu pemerintah desa dan Perhutani membatasi kayu yang boleh diambil untuk bahan bakar, yaitu kayu-kayu atau ranting-ranting pohon yang jatuh saja. Pemerintah desa juga memasyarakatkan penggunaan biogas sebagai sumber energi rumah tangga. Pemanfaatan biogas ini memberi efek positif bagi lingkungan karena mengurangi limbah kotoran sapi untuk kebutuhan lain yang lebih bermanfaat. Mikrohidro merupakan sumber energi alternatif yang dapat dikembangkan. Hanya saja teknologinya masih belum dikuasai oleh masyarakat. Sehingga untuk mengembangkannya memerlukan bantuan tenaga ahli dari luar desa.

e. Manajemen limbah mengalami perubahan yang berdampak positif bagi lingkungan, antara lain ditunjukkan oleh pemanfaatan biogas, pembangunan IPAL komunal untuk mengurangi pencemaran air sungai, dan pembuatan kompos. Perbaikan ini perlu terus dilanjutkan dan dikembangkan misalnya dengan melatih masyarakat mengembangkan seni kerajinan daur ulang limbah anorganik

\section{Embracing Co-creative Design Processes}

Masyarakat Desa Bendosari masih sangat menjunjung tinggi tradisi gotong royong.

Mereka bekerja sama dan saling bantu baik dalam bentuk materi, tenaga, maupun pemikiran dalam berbagai kegiatan.

\section{Simpulan}

Ditinjau dari 6 poin konsep ekologis Hui, 2001 (termasuk konsep ekologis Cowan dan Ryn, 1996) arsitektur di Desa Bendosari relatif masih memenuhi 'standar' sebagai arsitektur yang ekologis.

Arsitektur masyarakat Desa Bendosari masih cukup mampu mewadahi kebutuhan manusia-masyarakat serta sesuai dengan kondisi lokalitasnya. Desain arsitektur Desa Bendosari masih akomodatif atau sesuai dengan kondisi masyarakat (understanding people), memiliki keterkaitan dengan lingkungannya (connecting with nature), memiliki pemahaman terhadap proses-proses alamiah (understanding natural processes), semakin berupaya memperkecil dampak negatif terhadap lingkungan (understanding natural impact), dan hubungan sosial masih sangat kental sehingga gotong-royong dan kerja bakti dalam berbagai proses desain dan proses pembangunan merupakan modal sosial yang utama. Penerapan konsep-konsep ekologis pada arsitektur masyarakat Desa Bendosari ini juga didukung oleh aspek kepercayaan yang masih dipegang teguh. Masyarakat perlu diberi pemahaman mengenai nilai-nilai positif (terutama terkait konsep ekologis) yang terkandung dalam kepercayaan dan aturan-aturan adat mereka agar jika suatu saat nanti terjadi perubahan pada kepercayaan tradisional mereka, mereka tetap paham nilai-nilai ekologis yang harus tetap dijaga dari lingkungan mereka. 


\section{Ucapan Terima Kasih}

Ucapan terima kasih kami sampaikan kepada:

1. Fakultas Teknik Universitas Brawijaya dan BPP FT-UB yang telah memfasilitasi kegiatan penelitian ini.

2. Jurusan Arsitektur FT-UB

3. Kepala desa Bendosari beserta seluruh perangkat desa dan para nara sumber

\section{Daftar Pustaka}

1979. Cultural Origins of Architecture. New York: McGraw Hill.

Agoes Soegianto. 2005. Ilmu Lingkungan, Sarana Menuju Masyarakat Berkelanjutan. Surabaya: Airlangga University Press.

Broadbent G, Brebia CA. (ed). 2006. Eco-Architecture, Harmonization Between Architecture and Nature. Southampton, UK: WIT Press.

Budihardjo, Eko. 1996. Menuju Arsitektur Indonesia. Bandung: Penerbit Alumni.

Cowan, Stuart and van de Ryn, Sims. 1996. Ecological Design. USA: Island Press

Darjosanjoto, Endang Titi Sunarti. 2006. Penelitian Arsitektur di Bidang Perumahan \& Permukiman. Surabaya: ITS Press.

Frick, H, dan Mulyani, Tri Hesti. 2006. Arsitektur Ekologis. Yogyakarta: Penerbit Kanisius.

Frick, H., dan Suskiyanto, F.X. Bambang. 1998. Dasar-dasar Eko-Arsitektur. Yogyakarta: Penerbit Kanisius.

Hui, Sam C. M. 1996 (updated 2002). Sustainable Architecture. http://www.arch.hku.hk/research/beer/sustain.htm. Didownload November 2011.

Mackenzie, L.D., dan Masten, S.J. 2004. Principles of Environmental Engineering and Science. Singapore: Mc Graw Hill.

Moleong, Lexy J. 2002. Metodologi Penelitian Kualitatif. Bandung: Remaja Rosdakarya.

Muhadjir, Noeng. 1996. Metodologi Penelitian Kualitatif. Yogyakarta: Rake Sarasin.

Pangarsa, Galih W.P. 2007. Merah Putih Arsitektur Nusantara. Yogyakarta: Andi Offset

Papanek, 1972. The Green Imperative: Ecology and Ethics in Design and Architecture. USA:

Thames and Hudson

Rapoport, Amos. 1969. House Form and Culture. Engelwood Clifs: Prentice Hall-Inc.

Salura, Purnama. 2001. Ber-arsitektur: Membuat, Menggunakan Mengalami, dan Memahami Arsitektur. Bandung: Architecture \& Communication.

Vale, Brenda and Vale, Robert. 1992. Green Architecture: Design for an Energy-Conscious Future. Bulfinch Press Little Brown and Company

Williams, Daniel E. 2007. Sustainable Design: Ecology, Architecture and Planning. USA: John Willey and Sons 